Review began 12/07/2021 Review ended 12/20/2021 Published 12/23/2021

(c) Copyright 2021

Fagih et al. This is an open access article distributed under the terms of the Creative Commons Attribution License CC-BY 4.0. which permits unrestricted use, distribution, and reproduction in any medium, provided the original author and source are credited.

\section{Scrotal Necrosis Following Heated Intra- peritoneal Chemotherapy: Case Report and Review of the Literature}

\author{
Samiha N. Fagih ${ }^{1}$, Rana M. Baghdadi ${ }^{1}$, Aeshah Y. Banjer ${ }^{1}$, Amal A. Ismail ${ }^{1}$, Majda A. Addas ${ }^{1}$, Alaa A. \\ Shabkah $^{2}$, Nora H. Trabulsi ${ }^{1}$ \\ 1. Department of Surgery, King Abdulaziz University Faculty of Medicine, Jeddah, SAU 2. Department of Surgery, \\ International Medical Center, Jeddah, SAU
}

Corresponding author: Nora H. Trabulsi, noratrabulsi@gmail.com

\begin{abstract}
Scrotal necrosis is a rare occurrence that is scarcely reported among patients having undergone heated intraperitoneal chemotherapy (HIPEC) procedures. Due to anatomic factors and the thermally enhanced cytotoxicity of chemotherapeutic agents, this complication can have debilitating post-operative effects. We herein highlight the presentation of scrotal necrosis in a patient who underwent HIPEC procedure for peritoneal metastasis secondary to colorectal carcinoma, and how it contrasts to previously documented cases of a similar nature. Furthermore, we describe a successful management strategy that consisted of conservative measures followed by surgical debridement and primary repair, and enabled the patient to experience significant functional and cosmetic improvement.
\end{abstract}

Categories: Urology, General Surgery, Oncology

Keywords: hyperthermic intraperitoneal chemotherapy, colorectal cancer, cytoreductive surgery (crs), cytoreductive surgery and hipec, scrotal edema

\section{Introduction}

Heated intra-peritoneal chemotherapy (HIPEC) is utilized in the management of disseminated intraabdominal malignancies, such as colorectal [1], ovarian [2], appendiceal [3], and primary peritoneal neoplasms. It entails regional infusion of heated chemotherapy in adjunction to cytoreductive surgery (CRS). The chemotherapeutic agent acts synergistically with heat to target microscopic disease after the macroscopic tumor has been surgically excised. This has been shown to improve long-term disease-free and overall survival [4]. Mitomycin C (MMC) is frequently used in this context [5,6]. Despite its favorable profile, MMC is linked to side effects such as neutropenia (40\%) [7], respiratory complications (17\%), intraabdominal collections (8.8\%), anastomotic leaks (4.4\%), wound infections (7.2\%), ileus (6.2\%), and acute renal injury (5.6\%) [8]. A rare yet important complication is scrotal pain and ulceration after MMC administration in HIPEC. Only a few recorded cases have been described in the literature [9-13]. This is a case report of scrotal necrosis after HIPEC for adenocarcinoma of the colon with peritoneal metastasis (PM).

\section{Case Presentation}

A 39-year-old man presented with PM secondary to colorectal carcinoma. He had initially undergone an extended right hemicolectomy followed by adjuvant oxaliplatin and capecitabine (XELOX). Subsequent surveillance imaging revealed suspicious peritoneal deposits confirmed to be malignant through diagnostic laparoscopy and peritoneal biopsy. He underwent CRS including low anterior resection for a large infiltrative pelvic deposit, seminal vesicles resection, and peritonectomy along with MMC-based HIPEC.

A small number of pelvic ascites was noted intra-operatively. Cytological analysis of the fluid was obtained and showed malignant cells. This finding alongside the patient's clinical background and peritoneal cancer index (PCI) score of 11 , led to the decision to proceed with HIPEC. MMC was administered at $41^{\circ} \mathrm{C}$ for 90 minutes. The surgery was well-tolerated by the patient. His post-operative course was complicated by a urinary tract infection and paralytic ileus, which resolved shortly thereafter.

On post-operative day 30, he began to develop scrotal swelling and discoloration in the form of diffuse erythema with black spots (Figure 1, panel a). He was seen by the urology team, who recommended watchful waiting. His symptoms continued to progress. On post-operative day 52, he presented to the emergency department with worsening ulceration. He reported burning scrotal pain that radiated to his medial thigh and affected his mobility. Examination revealed scrotal tenderness with mild swelling. The overlying skin was erythematous with signs of eschar formation. Three necrotic demarcations were noted on the scrotum with ulceration associated with purulent discharge at the scrotopenile junction (Figure 1, panel b). 


\section{Cureus}

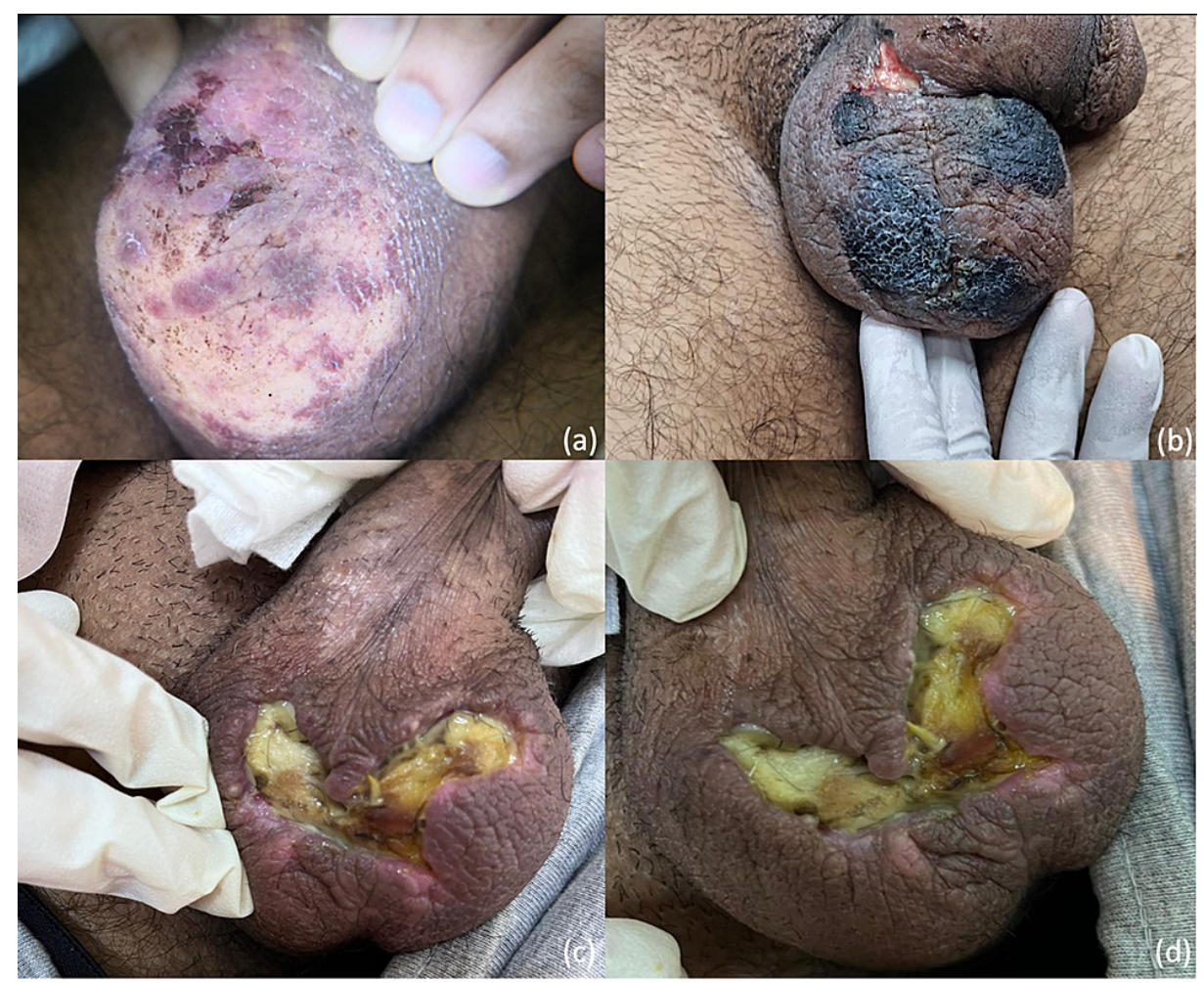

FIGURE 1: Progression of scrotal necrosis post mitomycin $C$ based heated intra-peritoneal chemotherapy (HIPEC)

The image is showing (a) early changes on anterior scrotal skin, (b) progression of scrotal necrosis, (c) exposed subcutaneous necrotic tissue, and (d) final stage prior to debridement and primary closure.

Upon admission, the patient's biochemical profile was unremarkable with normal cell counts and coagulation panel. Scrotal ultrasound ruled out underlying collections (Figure 2). Kidney-ureter-bladder ultrasound was unremarkable. Computed tomography of the pelvis ruled out recurrence and necrotizing fasciitis as well as deep collections (Figure 3). 


\section{Cureus}

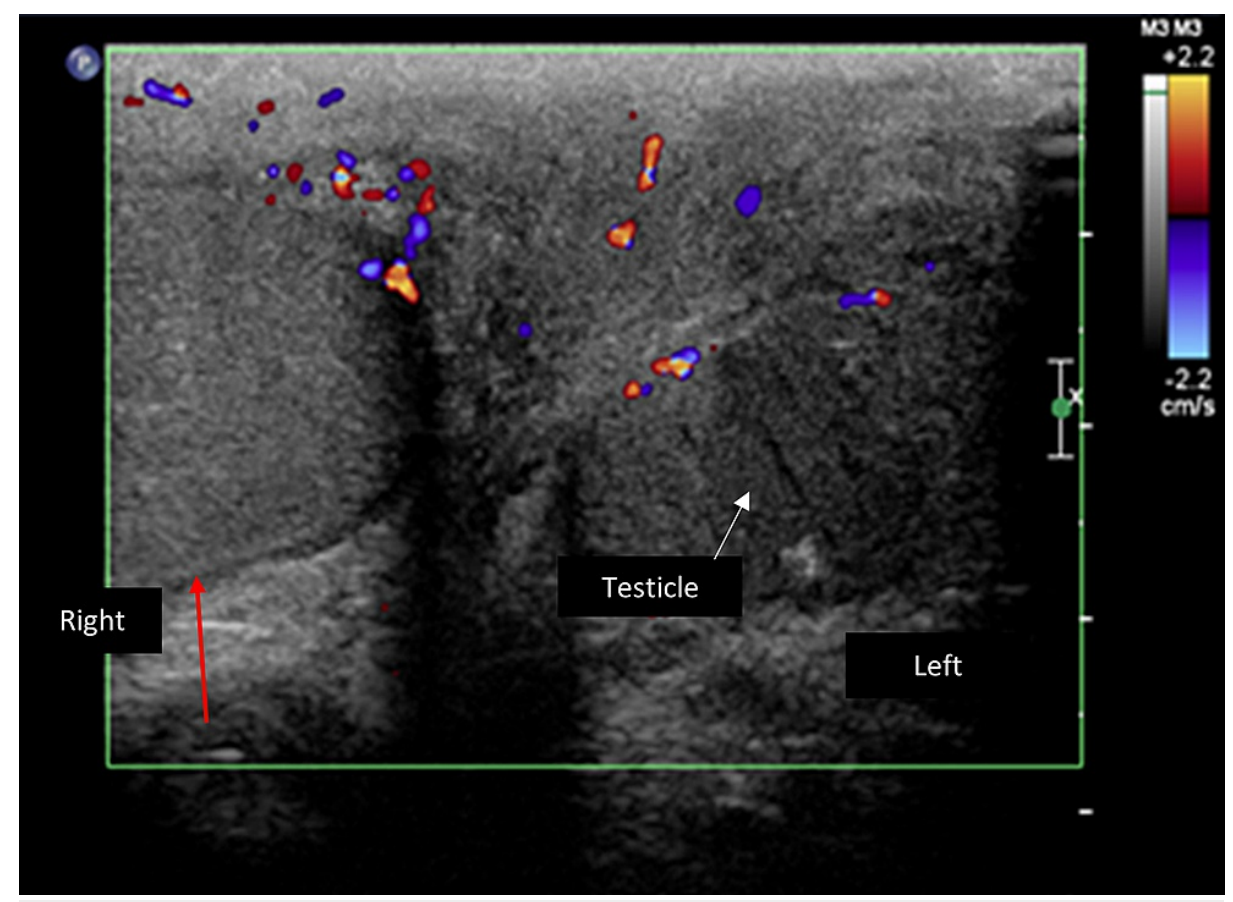

FIGURE 2: Scrotal ultrasound ruled out underlying collections.

The image is showing subcutaneous thickening and increased subcutaneous vascularity suggestive of scrotal cellulitis (red arrow: subcutaneous thickening; white arrow: left testicle).

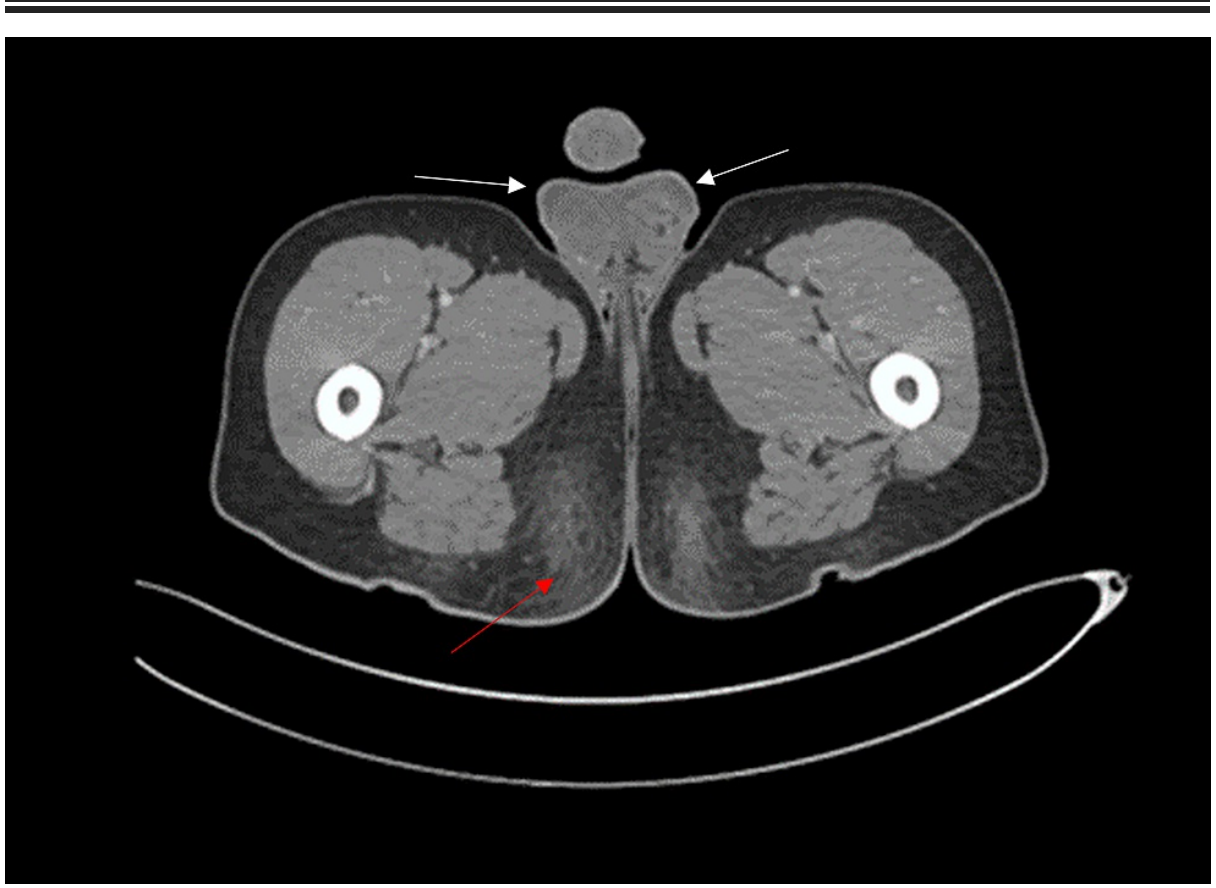

FIGURE 3: Axial view of computed tomography of the pelvis with IV contrast demonstrating diffuse subcutaneous edema with scrotal wall thickening bilaterally.

No soft tissue/fat stranding, fascial thickening nor free gas was noted (red arrow: diffuse subcutaneous edema; white arrow: scrotal wall thickening bilaterally).

The urology service was consulted. Their impression was that of gangrenous cellulitis, for which they recommended conservative management with antibiotics and local wound care. The patient received systemic and topical antibiotics with broad-spectrum and anti-fungal coverage (meropenem, vancomycin, 


\section{Cureus}

fluconazole, and topical silver sulfadiazine). Antibiotics were introduced on an empirical basis based on the clinical picture of purulent discharge. However, following a negative tissue culture result, we discontinued the antibiotics. Moreover, blood and urine cultures were negative for any growths and serological studies failed to identify an infectious process. The symptoms persisted and the scrotal lesions progressed (Figure 1, panel c).

Further consultations were sought from the dermatology service. Their differentials included gangrenous cellulitis, chemotherapy-induced vasculopathy, and pyoderma gangrenosum (PG), for which he was started on a regimen of high-dose topical steroids cream and flamazine. The patient subsequently began to demonstrate improvement within the following weeks. Figure 1, panel d, documents the resolution of the eschar with visible, well-demarcated necrotic tissue.

Meanwhile, the patient required multiple lines of narcotics for concomitant pudendal neuropathy. He eventually required an impar ganglion block by pain service. An anesthetic substance (bupivacaine and 100\% alcohol) is injected into the impar ganglion, which is positioned anterior to the sacrococcygeal joint. This resulted in a progressive reduction in his perineal pain and narcotic usage. On post-operative day 95 , the patient underwent surgical debridement and primary repair (Figure 4). Bilateral viable testicles were observed intra-operatively. Histopathological analysis showed mixed inflammatory and reactive changes.

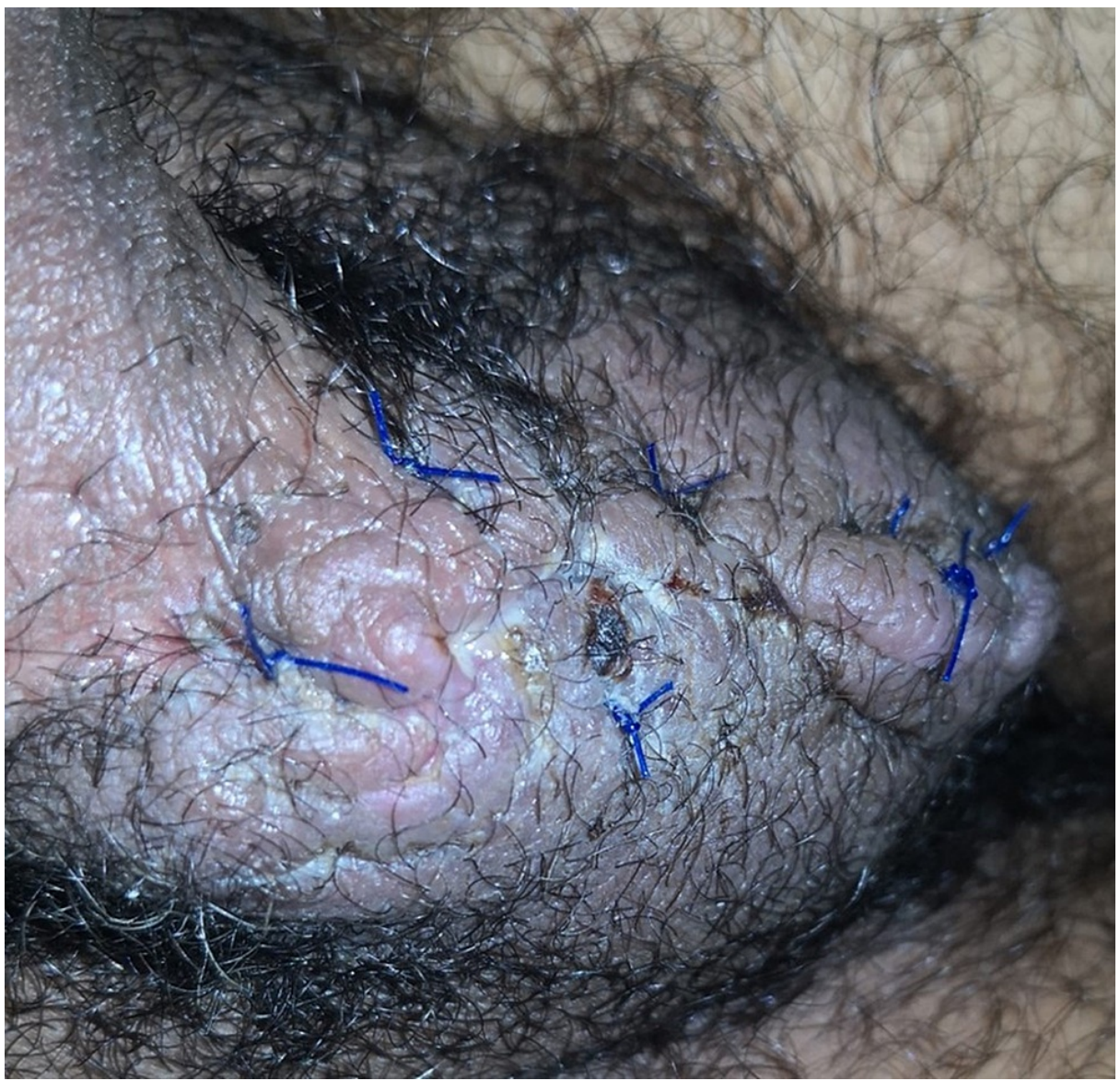

\section{FIGURE 4: Post-surgical debridement and primary repair.}

\section{Discussion}

Necrosis of the genitals is an infrequent yet devastating consequence of HIPEC. It manifests as the pain of the genitalia with apparent tissue devitalization during the post-operative phase. This is postulated to occur due to the underlying anatomy of patent processus vaginalis (PPV), which allows the chemotherapeutic agent to travel into the intra-scrotal region from the peritoneal cavity $[9,10]$. When this occurs intraoperatively, the scrotum cannot be evacuated simultaneously with the peritoneal cavity, leading to extended contact with MMC. As a result, the principle of hyperthermia-enhanced tissue penetration and cytotoxicity of MMC which makes HIPEC an effective treatment solution raises the risk of instigating a massive inflammatory response with resultant ulceration and necrosis.

The literature documenting this complication is limited. Table 1 summarizes the clinical data from five case reports [9-12], and one case series published by Baron et al. based on a total of 13 cases retrospectively 


\section{Cureus}

identified from two specialized centers [13]. MMC was used as the intra-peritoneal chemotherapy agent of choice for all 18 cases. The clinical data portrayed by the authors are largely consistent. The patients presented similarly with pain, scrotal swelling, and skin changes that ranged from diffuse erythema to welldemarcated gangrenous eschars. Systemic response in the form of fever, sepsis, and leukocytosis was not commonly encountered or reported. The timeline of this presentation was variable among the reported cases, from days to months post-operatively. Notably, resolution of symptoms necessitated surgical management among 14 out of 18 of the cases described. 


\section{Cureus}

\begin{tabular}{|c|c|c|c|c|c|c|c|c|c|}
\hline \multicolumn{10}{|l|}{ Case report } \\
\hline Authorlyear & Age & Type of malignancy & $\begin{array}{l}\text { Time of } \\
\text { presentation }\end{array}$ & MMC infusion & $\begin{array}{l}\text { Response to } \\
\text { antibiotics }\end{array}$ & $\begin{array}{l}\text { Laboratory } \\
\text { and cultures }\end{array}$ & Imaging & Resolution & Pathology \\
\hline $\begin{array}{l}\text { Case 1: Akhavan et al., } \\
2007 \text { [9] }\end{array}$ & 48 & $\begin{array}{l}\text { Metastatic appendiceal } \\
\text { adenocarcinoma }\end{array}$ & $\begin{array}{l}4 \text { months } \\
\text { post- } \\
\text { operatively }\end{array}$ & $\begin{array}{l}30 \mathrm{mg} \text { over } 60 \\
\text { minutes at } 41^{\circ} \mathrm{C} \\
\text { followed by } 10 \\
\mathrm{mg} \text { over } 40 \\
\text { minutes }\end{array}$ & $\begin{array}{l}\text { Minimal: pain } \\
\text { mildly improved }\end{array}$ & $\begin{array}{l}\text { Blood and } \\
\text { urine } \\
\text { cultures } \\
\text { negative for } \\
\text { growths }\end{array}$ & $\begin{array}{l}\text { Right-sided } \\
\text { hydrocele and } \\
\text { testicular hyperemia } \\
\text { with scrotal wall } \\
\text { thickening } \\
\text { Negative for } \\
\text { abscess/Fournier's } \\
\text { gangrene }\end{array}$ & $\begin{array}{l}\text { Surgical excision of } \\
\text { the ulcer and } \\
\text { surrounding necrotic } \\
\text { tissue followed by } \\
\text { primary repair }\end{array}$ & $\begin{array}{l}\text { Necrosis and } \\
\text { granulation }\end{array}$ \\
\hline $\begin{array}{l}\text { Case 2: Akhavan, et al., } \\
2007 \text { [9] }\end{array}$ & 66 & $\begin{array}{l}\text { Recurrent peritoneal } \\
\text { mesothelioma }\end{array}$ & $\begin{array}{l}3 \text { months } \\
\text { after the } \\
\text { second } \\
\text { HIPEC in } 2 \\
\text { years }\end{array}$ & $\begin{array}{l}30 \mathrm{mg} \text { over } 60 \\
\text { minutes followed } \\
\text { by } 10 \mathrm{mg} \text { over } 40 \\
\text { minutes }\end{array}$ & $\begin{array}{l}\text { Initial response } \\
\text { followed by } \\
\text { recurrence } 2 \\
\text { months later }\end{array}$ & $\begin{array}{l}\text { Cultures } \\
\text { negative for } \\
\text { growths }\end{array}$ & $\begin{array}{l}\text { Negative for } \\
\text { collections }\end{array}$ & $\begin{array}{l}\text { Excision followed by } \\
\text { primary repair }\end{array}$ & $\begin{array}{l}\text { Inflammatory } \\
\text { changes and } \\
\text { reactive } \\
\text { fibrosis }\end{array}$ \\
\hline $\begin{array}{l}\text { Case 3: Aziz et al., } \\
2015 \text { [11] }\end{array}$ & 33 & $\begin{array}{l}\text { Pseudomyxoma peritonei } \\
\text { of appendiceal origin }\end{array}$ & $\begin{array}{l}2 \text { months } \\
\text { (Post- } \\
\text { operative } \\
\text { Day 67) }\end{array}$ & $\begin{array}{l}18 \mathrm{mg} \text { over } 60 \\
\text { minutes at } 42^{\circ} \mathrm{C}\end{array}$ & Not mentioned & $\begin{array}{l}\text { Cultures } \\
\text { negative for } \\
\text { growths }\end{array}$ & $\begin{array}{l}\text { Scrotal skin } \\
\text { thickening } \\
\text { Negative for } \\
\text { collections }\end{array}$ & $\begin{array}{l}\text { Excision followed by } \\
\text { primary repair }\end{array}$ & Not mentioned \\
\hline $\begin{array}{l}\text { Case 4: Fabiana et al., } \\
2012 \text { [10] }\end{array}$ & 65 & $\begin{array}{l}\text { Metastatic rectal } \\
\text { adenocarcinoma }\end{array}$ & 9 days & Not specified & No response & $\begin{array}{l}\text { Cultures } \\
\text { negative for } \\
\text { growths }\end{array}$ & $\begin{array}{l}\text { Negative for } \\
\text { collections }\end{array}$ & $\begin{array}{l}\text { Wound debridement } \\
\text { and primary repair }\end{array}$ & $\begin{array}{l}\text { Ischemic } \\
\text { necrosis on } \\
\text { punch biopsy }\end{array}$ \\
\hline $\begin{array}{l}\text { Case 5: Bartlett et al., } \\
2019 \text { [12] }\end{array}$ & 54 & $\begin{array}{l}\text { Metastatic appendiceal } \\
\text { carcinoid adenocarcinoma }\end{array}$ & 3 months & Not specified & Not mentioned & $\begin{array}{l}\text { Not } \\
\text { mentioned }\end{array}$ & $\begin{array}{l}\text { CT pelvis showed } \\
\text { bilateral hydroceles } \\
\text { without abscess or } \\
\text { collection } \\
\text { US showed scrotal } \\
\text { thickening without } \\
\text { masses or collections }\end{array}$ & $\begin{array}{l}\text { Initial improvement } \\
\text { with topical } 60 \% \\
\text { dimethyl sulfoxide } \\
\text { (DMSO) followed by } \\
\text { debridement and } \\
\text { partial scrotal } \\
\text { resection }\end{array}$ & $\begin{array}{l}\text { Epidermal } \\
\text { necrosis } \\
\text { without } \\
\text { evidence of } \\
\text { vasculitis }\end{array}$ \\
\hline Case series & & & & & & & & & \\
\hline $\begin{array}{l}13 \text { patients reported by } \\
\text { Baron et al., } 2021 \text { [13], } \\
\text { from two peritoneal } \\
\text { malignancy centers with } \\
\text { a total of } 1597 \text { HIPEC }\end{array}$ & $\begin{array}{l}\text { Median } \\
\text { age: } \\
57 \\
\text { (IQR: } \\
\text { 49-64) }\end{array}$ & $\begin{array}{l}8(62 \%) \text { appendiceal, } 3 \\
(23 \%) \text { Colon, } 1(8 \%) \\
\text { gastric tumors, and } 1(8 \%) \\
\text { mesothelial cysts. } \\
\text { (histological subtypes not } \\
\text { specified) }\end{array}$ & $\begin{array}{l}\text { Median: } 64 \\
\text { days (IQR: } \\
60-108)\end{array}$ & $\begin{array}{l}40 \mathrm{mg} \text { in } 11 / 13 \\
\text { patients, } 28 \mathrm{mg} \\
\text { in } 1 / 13 \text { patient } \\
\text { and } 22 \mathrm{mg} \text { in } \\
1 / 13 \text { patient } \\
\text { Perfusion was } \\
\text { over } 90 \text { minutes } \\
\text { in } 11 / 13 \text { patients } \\
\text { and over } 60 \\
\text { minutes in 2/13 } \\
\text { patients }\end{array}$ & $\begin{array}{l}\text { Trial of } \\
\text { conservative } \\
\text { therapy with } \\
\text { antibiotics in } 8 / 13 \\
\text { of patients with } \\
\text { inadequate } \\
\text { response }\end{array}$ & $\begin{array}{l}\text { Median cell } \\
\text { counts at } \\
\text { time of } \\
\text { genital } \\
\text { necrosis } \\
\text { WBC } \\
\left(\times 10^{9 / L):}\right. \\
9.0(7.2- \\
12.5) \\
\text { Hemoglobin } \\
(\mathrm{g} / \mathrm{dL}): 11.3 \\
(9.8-12.8) \\
\text { Platelets } \\
\left(\times 10^{9} / \mathrm{L}\right): \\
457(369- \\
551)\end{array}$ & $\begin{array}{l}\text { Hydrocele }(n=3) \text {, } \\
\text { labia tissue edema ( } n \\
=1) \text {, scrotal wall } \\
\text { thickening }(n=3) \text {, and } \\
\text { subcutaneous } \\
\text { emphysema }(n=1)\end{array}$ & $\begin{array}{l}\text { Median time between } \\
\text { presentation and } \\
\text { surgical treatment of } \\
57 \text { days (IQR: 8-180) }\end{array}$ & $\begin{array}{l}\text { Pathology } \\
\text { reports were } \\
\text { available for } \\
5 / 9 \text { of the } \\
\text { patients that } \\
\text { underwent } \\
\text { debridement }\end{array}$ \\
\hline
\end{tabular}

\section{TABLE 1: Review of literature on HIPEC-associated scrotal necrosis}

HIPEC: hyperthermic intra-peritoneal chemotherapy; IQR: inter-quartile range; US: ultrasound; CT: computed tomography; WBC: white blood cell

This case is unique in its relatively early presentation following HIPEC. Whether this is due to patient- 
related or procedural factors has not been determined. Moreover, the rate of progression of the lesion and its positive response to steroids have not been described elsewhere. Other authors have documented minimal to partial improvement of symptoms with systemic antibiotics [9,13]. Fabiana et al. also reported partial improvement with topical scavenger agent dimethyl sulfoxide [10]. While this approach was deemed inadequate, Baron et al. highlighted the significance of early conservative measures to prevent premature operative management [13]. The anti-inflammatory effects of the aforementioned agents may mitigate the response elicited by MMC and allow the lesions to demarcate prior to surgical excision. This is supported by two cases that were prematurely excised and complicated by impaired wound healing and secondary necrotic lesions [13].

Some authors have suggested screening for PPV with pre-operative imaging or intra-operative identification to prevent this complication $[10,11]$. The underlying anatomy of PPV has been extensively studied in the context of peritoneal dialysis patients presenting with scrotal edema and post-prostatectomy patients presenting with inguinal hernia $[14,15]$. The radiological demonstration of PPV via radionucleotide scintigraphy and CT peritoneography has been used to predict genital edema among peritoneal dialysis patients $[14,15]$. Lee et al. described intra-operative identification of PPV by looking for a dimple with or without an associated visible canal towards the deep inguinal ring [16]. Others have extrapolated his findings by exploring methods of PPV occlusion to prevent inguinal hernia post-prostatectomy [17,18]. To our knowledge, none of these approaches have been performed in HIPEC procedures.

\section{Conclusions}

More cases should be recorded to ensure a better understanding of the etiology and natural course of this complication and to determine which populations are at a higher risk of developing it. Moreover, it is vital to promote awareness among surgeons who may incorporate this into their pre-operative counseling for patients undergoing HIPEC procedures.

\section{Additional Information \\ Disclosures}

Human subjects: Consent was obtained or waived by all participants in this study. Conflicts of interest: In compliance with the ICMJE uniform disclosure form, all authors declare the following: Payment/services info: All authors have declared that no financial support was received from any organization for the submitted work. Financial relationships: All authors have declared that they have no financial relationships at present or within the previous three years with any organizations that might have an interest in the submitted work. Other relationships: All authors have declared that there are no other relationships or activities that could appear to have influenced the submitted work.

\section{References}

1. Kuijpers AM, Mirck B, Aalbers AG, et al.: Cytoreduction and HIPEC in the Netherlands: nationwide longterm outcome following the Dutch protocol. Ann Surg Oncol. 2013, 20:4224-30. 10.1245/s10434-013-3145-9

2. Spiliotis J, Halkia E, Lianos E, Kalantzi N, Grivas A, Efstathiou E, Giassas S: Cytoreductive surgery and HIPEC in recurrent epithelial ovarian cancer: a prospective randomized phase III study. Ann Surg Oncol. 2015, 22:1570-5. 10.1245/s10434-014-4157-9

3. Mehta A, Mittal R, Chandrakumaran K, et al.: Peritoneal involvement is more common than nodal involvement in patients with high-grade appendix tumors who are undergoing prophylactic cytoreductive surgery and hyperthermic intraperitoneal chemotherapy. Dis Colon Rectum. 2017, 60:1155-61. 10.1097/DCR.0000000000000869

4. Witkamp AJ, de Bree E, Van Goethem R, Zoetmulder FA: Rationale and techniques of intra-operative hyperthermic intraperitoneal chemotherapy. Cancer Treat Rev. 2001, 27:365-74. 10.1053/ctrv.2001.0232

5. Sugarbaker PH, Mora JT, Carmignani P, Stuart OA, Yoo D: Update on chemotherapeutic agents utilized for perioperative intraperitoneal chemotherapy. Oncologist. 2005, 10:112-22. 10.1634/theoncologist.10-2-112

6. Kitayama J: Intraperitoneal chemotherapy against peritoneal carcinomatosis: current status and future perspective. Surg Oncol. 2014, 23:99-106. 10.1016/j.suronc.2014.03.004

7. Lambert LA, Armstrong TS, Lee JJ, et al.: Incidence, risk factors, and impact of severe neutropenia after hyperthermic intraperitoneal mitomycin C. Ann Surg Oncol. 2009, 16:2181-7. 10.1245/s10434-009-0523-4

8. Tan GH, Shannon NB, Chia CS, Soo KC, Teo MC: Platinum agents and mitomycin C-specific complications in cytoreductive surgery (CRS) and hyperthermic intraperitoneal chemotherapy (HIPEC). Int J Hyperthermia. 2018, 34:595-600. 10.1080/02656736.2017.1345014

9. Akhavan A, Yin M, Benoit R: Scrotal ulcer after intraperitoneal hyperthermic chemotherapy. Urology. 2007, 69:9-10. 10.1016/j.urology.2007.02.010

10. Fabiana S, Avancini J, Criado P, Pfiffer T, Lobo A, Sanches J: Scrotal ulcer developed after intraperitoneal hyperthermic chemotherapy with mitomycin-C. BJU Int. 2012, 10.1002/BJUIw-2012-019-web

11. Aziz NH, Wang W, Teo MC: Scrotal pain and ulceration post HIPEC: a case report . J Gastrointest Cancer. 2015, 46:60-3. 10.1007/s12029-014-9665-0

12. Bartlett K, Derrington S, Jariwala N, Mai C, Koo B: Scrotal ulceration: a complication of hyperthermic intraperitoneal chemotherapy and subsequent treatment with dimethyl sulfoxide. Cutis. 2019, 104:1-3.

13. Baron E, Velez-Mejia C, Sittig M, et al.: Delayed genital necrosis after cytoreductive surgery and hyperthermic intraperitoneal chemotherapy with mitomycin-c. Eur J Surg Oncol. 2021, 47:2352-7. 10.1016/j.ejso.2021.04.002 


\section{Cureus}

14. Bhattacharya A, Mittal BR: Peritoneo-scrotal communication: demonstration by 99mtechnetium sulphur colloid scintigraphy. Australas Radiol. 2005, 49:335-7. 10.1111/j.1440-1673.2005.01446.x

15. Xie JY, Chen N, Shi T, Xu ZP, Lu Y, Ren H: Computed tomographic peritoneography in the investigation of patent processus vaginalis in CAPD patients. Clin Nephrol. 2010, 73:153-6. 10.5414/cnp73153

16. Lee DH, Jung HB, Chung MS, Lee SH, Chung BH: Patent processus vaginalis in adults who underwent robotassisted laparoscopic radical prostatectomy: predictive signs of postoperative inguinal hernia in the internal inguinal floor. Int J Urol. 2013, 20:177-82. 10.1111/j.1442-2042.2012.03118.x

17. Kanda T, Fukuda S, Kohno Y, Fukui N, Kageyama Y: The processus vaginalis transection method is superior to the simple prophylactic procedure for prevention of inguinal hernia after radical prostatectomy. Int J Clin Oncol. 2016, 21:384-8. 10.1007/s10147-015-0881-9

18. Iwamoto H, Morizane S, Hikita K, Honda M, Takenaka A: Postoperative inguinal hernia after roboticassisted radical prostatectomy for prostate cancer: evaluation of risk factors and recommendation of a convenient prophylactic procedure. Cent European J Urol. 2019, 72:418-24. 10.5173/ceju.2019.0002 